\title{
IMPACT OF PSYCHOSOCIAL FACTORS ON NURSES SELF-SATISFACTION
}

\author{
Viljaras Reigas ${ }^{1}$, Danguolè Drungilienè², Geriuldas Žiliukas² \\ ${ }^{1}$ Klaipèda Nursing Hospital, ${ }^{2}$ Klaipeda University, Lithuania
}

Key words: psychosocial factors, nurses, self-satisfaction, quality of life.

\begin{abstract}
Summary
The aim of the research is to evaluate the impact of psychosocial factors on nurses' self-satisfaction. The research was completed in 2016 in stationary personal healthcare institutions. The research method was survey. The questionnaire includes two other questionnaires PSO-100 and WHS. 1182 people participated in this research. The highest level of self-dissatisfaction among nurses was noticed while the authors analyzed their sleep quality, energy, and health assessment. The most often negative psychosocial factors in the working environment were giving meaningless tasks, negative glances or/and gestures. Possibly, the more often the nurses experience a negative impact of a psychosocial factor, the wors they assess their self-satisfaction.
\end{abstract}

\section{Introduction}

Independently of what products are produced and what services are provided by an organization, up-to-date laws are topical: technology development, economic changes of society, democratic processes, personnel changes, market demand, micro and macro economic laws. At the same time organizations providing healthcare services are unique, since proof-based management of healthcare institutions are inherent to them where human resources are one of the areas of management.

While analysing self-satisfaction of nurses and relations with their job satisfaction a psychosocial job environment becomes a very important element. Psychosocial stresors in a job environment of nurses are factors having impact on provided service quality and safety, work capacities, social relationships not only inside the organization, but outside as well. In this research negative psychosocial factors are understood as factors having a negative impact on working nurses (isolation, gossiping, shouting, humiliating behaviour, depreciating opinion, salaries, etc.). Various authors adress such factors as psychosocial job stresors that have an impact on nurses' quality of life and their self-satisfaction.

Quality of life is a very important concept in various sciences. The concept of quality of life is difficult to be defined, since the concepts of life and quality seperately are difficult to be understood, but their composition is a complex phenomenon.

Nursing work is one of those characterized as having the highest level of psychologic stress. Many research has shown that stress experienced by nurses have an impact on their quality of life. Conflicts with doctors and administration, lack of patient honour and discrimination are those factors having impact on nurses' self-assessment $[1,9]$. According to the research completed in Norway it was stated that the factors influencing a higher level of job satisfaction of nurses are autonomy, low level of monotonous work, low level of job stress [2]. The other also very important factor having impact on satisfaction of clinical nursing work is a sense of adequate competences [3].

The research conducted in Lithuania states that limitation of self-expression possibilities, situations when research participants were somehow purposefully frustrated, experienced loud shouting, isolation are those factors of their psychologic harassement. These factors are spread among many organizations. Having an assumption that because of the unique activity workers of personal healthcare institutions more often than workers of other professions experience psychologic harassement. This research also states that the most often forms of psychologic harassement are situations when a worker was loudly shouted at $(17,3 \%)$ or criticized $(17,4 \%)$, lies were told about a worker $(23,9 \%)$. More rare forms of psychologic harassement are blaming others for having mental dissabilities or isolation [4].

It is important to pay attention to the fact that self-satisfaction of nurses is also closely connected with emotions at work, organizational culture and nursing management. It 
was figured out that a higher level of nurses` job satisfaction depends on organizational management, salary, status in an organization, motivation for development, safety, and working hours. The research has shown that nursing administrators are more satisfied with teir job than nurses without any managing positions [5]. The higher level of nurses job satisfaction also depends on personal characteristics of nurses, job organization and organizational characteristics [6].

Nurses' job satisfaction is connected with nurses' opinion about their job requirements. A special attention while eveluating nurses' job satisfaction should be paid to a personnel number and possibilities for combining work and personal life [7]. Therefore, the attention should be paid to clear regulation of nurses' functions at work [8].

The aim of the research is to evaluate the impact of psychosocial factors on nurses' self-satisfaction.

Research material and methods, research description

Nurses of stationary personal healthcare institutions participated in the research in 2016. The research was based on the survey including two questionnaires. The firs part was Quality of life questionnaire adapted to use in the Lithuanian setting (WHOQOL-100, Lithuanian PSO-100). The questionnaire includes 100 questions reflecting 7 areas of quality of life. The questionnaire includes general questions that helps to evaluate participants' quality of life, health, physical state of being (pain, unpleasant senses, thinkng, attention, sense of a personal value, independence - possibility to move and work, addiction to drugs), social relations (social care, personal relationships, sexual life), impact of environment (safety, financial possibilities, access to health ans social care and their quality, possibility to receive information), the meaning of spirituality and religiousness while coping with difficulties in life. The second part of the survey is dedicated to the scale of harassement at work (WHS). This scale includes 24 questions. Statements are evaluated applying the 5 point sistem Likert scale from 0 to 4 .

The research was conducted in those personal healthcare institutions that agreed to participate in the research. The questionnaires were given to the nurses that agreed to answer the questions.

The research data was analysed using SPSS 20.0 v. statistical analysis paskage. „MS Excel 2007“ tables were used for storage of variables. The hypotheses about two variables independence were verified on the basis of data type, related tabulation method using chi square $\left(\chi^{2}\right)$ value and its statistical meaning $p$. In order to verify the hypotheses the level of significance was chosen as 0,05 . The hypotheses about equality were ignored (differences were accepted as statistically significant and reliable) as the calculated value of the package did not exceed 0,05 .

While analysing the connection between quality of life and psychologic harassement, the responses of the participants were recalculated as „Experienced psychologic harassement" and „Did not experience psychologic harassement", where the responses of the participants ranging from 1 to 4 meant that they had „Experienced psychologic harassement“" and responses that equaled 0 meant that the participants „Did not experience psychologic harassement".

\section{Research results}

Demographic indicators. 93 (7.9\%) men and 1080 (92.1 $\%$ ) women participated in the research. $76.5 \%$ of the total umber of the participant stated that they live not alone, that is with the other person. Evaluating the gathered data, the authors found out that $14.1 \%$ of the participants living alone (without the other person at home) were not satisfied with their quality of life. At the same time two times less (7.4\%) participants living with the other person at home were not satisfied with their quality of life $(p<0,001)$. While completing the demographic analysis of the participants it is stated that $62.0 \%$ have professional education, $23.1 \%$ have graduated from universities and $14.9 \%$ from colleges. While evaluating the participants having chronic non-infectuous deseases, it is stated that more than a half $51.1 \%$ of the participants have heart and blood vessels deseases (almost half of them have higher arterial blood pressure). Almost a quarter (23.0\%) stated that they experience disorders of the digestive system. The research data of the participants age has shown that the youngest participant was 22 years old, the oldest was 76 years old. The average age of the participants was 45 years. $58.8 \%$ of the participants indicated that they lived in the cities, $32.3 \%$ live in small towns and $8.9 \%$ live in villages. Analysing the connection between participants" quality of life and their income, it is clear that $65.8 \%$ of the participants having more than 593 Eur of a monthly salary stated that they are satisfied with their quality of life. At the same time $19.1 \%$ of the participants having not more than 400 Eur of a monthly salary stated that they are not satisfied with their quality of life $(p<0,001)$. The research has shown that $13,3 \%$ of the participants that are dissatisfied with their quality of life work in the department of infectious diseases and health maintenance and nursing, $15.1 \%$ of the participants work in department of neurology, $19.4 \%$ of the paricipants work in the department of obstetrics and gynecology $(p<0,001)$.

Evaluation of self-satisfaction. While analising the nurses' self-satisfaction, the authors focused on such aspects as satisfaction with their quality of life, health, energy, sleep quality, ability to assimilate new information, ability to make decisions, self-satisfaction, satisfaction with personal abilities 
and body-image, ability to complete everyday life tasks and to maintain personal relations.

Evaluating the nurses' satisfaction with ealier presented indications, it is clear that $74,1 \%$ of the nurses are satisfied with their personal relationships, $73,9 \%$ of them are satisfied with their abilities to complete their everyday life tasks, $69,3 \%$ or the participants are satisfied with their abilities, $68,1 \%$ of them are satisfied with their abilities to make decisions, $65,5 \%$ of he nurses ' participated in the research are satisfied with their abilities to assimilate information, $64,5 \%$ of them are self-satisfied, $61,4 \%$ of them are satisfied with their life, $59,4 \%$ of the nurses ' are satisfied with their bodyimage, $59,1 \%$ of them are satisfied with their energy, $57,2 \%$ of the participants are satisfied with their sleep quality, 55,8\% of them are satisfied with their health, and $50,9 \%$ of them are satisfied with their quality of life.

The highest level of dissatisfaction is noticed while evaluating the participants' sleep quality ( 16,8 proc.), energy (11,8 proc.), health (11,2 proc.), ability to assimilate information ( 8,6 proc.), abilities to make decisions ( 7,4 proc.), body-image $(6,9$ proc.), personal relations $(5,4$ proc.), selfsatisfaction (4,4 proc.), ability to complete everyday life tasks ( 4,1 proc.), and abilities ( 3,6 proc.).

Evaluation of impact of negative psychosocial factors on self-satisfaction. During the last 6 months $7,1 \%$ of the participants experienced restrictions of self-expression, $7,7 \%$ they experienced the nurses' lies told about the research participants to other people, $3,5 \%$ of the participants experienced the situations when they were purposefully frustrated, $4,8 \%$ they experienced situations when nurses were screamed at loudly, $4,3 \%$ the research participants experienced situations when they were overcriticized, $4,9 \%$ of the nurses experienced insulting comments about nurses' personal life.

The analysis of the impact of the negative psychosocial factors on self-satisfaction has indicated that during the last 6 months $30,4 \%$ of the nurses experienced the restriction of the abilities of self expression, $52,5 \%$ of the participants exprerienced lies told to other people, $69,4 \%$ of them experienced situations of purposeful frustration, of loud screaming $(33,4$ proc.), isolation (78,6 proc.), negative gestures or blaming glances (53,3 proc.), depreciation of opinions ( 78,6 proc.), doubts of others because of the decisions made (76,2 proc.), and they are not satisfied with their health $(\mathrm{p}<0,001)$.

The research results have shown that $84,8 \%$ of the participants are dissatisfied with their energy level since during the last 6 months they experienced the restrictions of selfexpression abilities, telling lies to other people $(56,4 \%)$, situations when they were purposefully frustrated $(72,2 \%)$, situations when they were screamed at loudly $(50,0 \%)$, situations when they were overcriticised $(58,3 \%)$, they experi- enced blaming glances and / or gestures $(40,0 \%)$, unreasonable blames $(42,2 \%)$, depreciation of opinions $(64,3 \%)$, evil gossiping $(46,7 \%)$, and doubts of others about the decisions made $(42,9 \%)(\mathrm{p}<0,001)$.

The research has shown the satisfaction with sleep quality of those participants who during the last 6 months have experienced the restrictions to self-expression $(51,1 \%)$, situations when they were loudly mocked $(47,2 \%)$, isolation $(64,3 \%)$, publication of delicate details of personal life $(83,3 \%)$, direct threatening $(50,0 \%)$, humiliating behaviour and /or glances, refusal to talk, insulting comments about their personal life, direct threatening $(100,0 \%)$, depreciation of opinion $(78,6 \%)$, insulting words $(66,6 \%)$, evil gossiping $(70,0 \%)$, incorrect evaluation of work $(66,7 \%)(p<0,001)$.

During the last 6 months $42,3 \%$ of the participants who experienced self-expression restriction, $33,3 \%$ on them who experienced situations of puroseful frustration, and $64,3 \%$ of them who experienced depreciation of opinions stated that they were not satisfied with their abilities to assimilate new information $(p<0,001)$.

During the last 6 months $61,7 \%$ of the participants who experienced self-expression restriction, $47,7 \%$ of them who experienced purposeful frustration, $50,0 \%$ of them who experienced isolation, $64,3 \%$ of the participants who experienced depreciation of opinions, and $61,9 \%$ of the participants who experienced doubts of others about the decisions made stated that were not satisfied with their abilities to make decisions.

During the last 6 months $51,1 \%$ of the participants who experienced self-expression restrictions, $47,2 \%$ of the participants who experienced situations when they were purposefully frustrated and $64,3 \%$ of the participants who experienced depreciation of opinion stated that they are selfdissatified.

During the last 6 months $42,4 \%$ of the nurses that experienced self-expression restriction and 50,0\% of the nurses who experienced depreciation of opinions stated that they are not satisfied with their abilities $(\mathrm{p}<0,001)$.

During the last 6 months $33,3 \%$ of the participants who experienced loud screaming at them, $50,0 \%$ of the participants who experienced isolation, $28,6 \%$ of the participants who experienced direct threatening and $47,6 \%$ of the participants who experienced doubts of others about the decisions made stated that they are not satisfied with their body-image $(\mathrm{p}<0,001)$.

During the last 6 months $50,0 \%$ of the participants who experienced isolation, $28,6 \%$ of the participants who experienced direct threatening, and $33,3 \%$ of the participants who experienced doubts of others about the decisions made stated that they are not satisfied with their abilities to complete everyday life tasks $(\mathrm{p}<0,001)$. 


\section{Conclusions}

1. Every third nurse is satisfied with his or her presonal relations, abilities to complete everyday life tasks, and his or her abilities. The highest level of nurses ' dissatisfaction was found while their sleep quality, energy, and health were analysed. Most often such negative psychosocial factors as giving tasks without any purpose $(6,1 \%)$ and blaming glances and/or gestures occur at work $(5,2 \%)$.

2. The research has shown that negative psychosocial factors of the nurses are closely related with the evaluation of self-satisfaction. The more often the negative psychosocial factors are experienced by nurses, the worse they evaluate self-satisfaction.

\section{References}

1. Sarafis P, Rousaki E, Tsounis A, Malliarou M, Lahana L, Bemidis P, Niakas D, Papastavrou E. The impact of occupational stress on nurses' caring behaviors and their health related quality of life. BMC Nurs 2016;(15)56:231-239.

https://doi.org/10.1186/s12912-016-0178-y

2. Andersen I H, Hansen T, Grov E K. Norwegian nurses' quality of life, job satisfaction, as well as intention to change jobs. Nordic Journal of Nursing Research 2016;4:23-31.

3. Kim K, Han Y, Kwak Y, Kim J. Professional quality of life and clinical competencies among Korean Nurses. Asian Nursing Research 2015;(9)3:200-206.

https://doi.org/10.1016/j.anr.2015.03.002

4. Lorber M, Savič S. Job satisfaction of nurses and identifying factors of job satisfaction in Slovenian Hospitals. Croat Med Journal 2012;53(3): 263-270.

https://doi.org/10.3325/cmj.2012.53.263

5. Wang Y, Dong W, Mauk K, Li P, Wan J, Yang G, Fang L, Huan W, Chen C, Hao M. Nurses' practice environment and their job satisfaction: a study on nurses caring for older adults in Shanghai. PLOS. 2015.
6. Kvist T, Mantynen R, Pastanen P, Turunen H, Miettinen M, Vehvilainen-Julkunen $\mathrm{K}$. The job satisfaction of finnish nursing staff: the development of a job satisfaction scale and survey results. Nursing Research and Practice 2012;(10):1-11.

https://doi.org/10.1155/2012/210509

7. Bacha A M, Grassiotto O, Gonçalves S P, Higa R, FonsechiCarvasan G A, Machado H, Cacique D B. Job satisfaction of nursing staff in a university hospital. Rev Bras Enferm $2015 ;(68) 6: 819-826$.

8. Zahaj M, Saliaj A, Metani L, Nika S, Alushi E. Factors related to job satisfaction among nurses. European Scientific Journal 2016;(2)5:100-110.

\section{PSICHOSOCIALINIŲ VEIKSNIŲ ITAKA SLAUGYTOJŲ PASITENKINIMUI SAVIMI V. Reigas, D. Drungilienė, G. Žiliukas}

Raktažodžiai: psichosocialiniai stresoriai, slaugytojai, pasitenkinimas savimi, gyvenimo kokybè.

Santrauka

Tyrimo tikslas - įvertinti psichosocialinių veiksnių įtaką slaugytojų pasitenkinimui savimi. Tyrimas atliktas 2016 metais stacionarinèse asmens sveikatos priežiūros įstaigose, jo metodas - anketinè apklausa.

Anketą sudarè du klausimynai: PSO-100 ir WHS. Tyrime dalyvavo 1182 respondentai. Didžiausias slaugytojų nepasitenkinimas užfiksuotas analizuojant jų miego kokybę, energiją bei sveikatos vertinimą. Dažniausiai darbo aplinkoje pasitaikantys neigiami psichosocialiniai veiksniai - bereikšmių užduočių skyrimas ir neigiami žvilgsniai ir ar gestai. Galima prielaida, kad kuo dažniau slaugytojas patiria neigiamo psichosocialinio veiksnio poveikį, tuo prasčiau jis vertina pasitenkinimą savimi.

Adresas susirašinèti: reigas.viljaras@gmail.com

Gauta 2017-11-06 